\title{
PENGARUH PENYULUHAN KESEHATAN TENTANG MENYUSUI DENGAN METODE DEMONSTRASI TERHADAP KEMAMPUAN IBU MENYUSUI DI RUMAH BERSALIN WILAYAH BANJARSARI SURAKARTA
}

\author{
Sri Lestari Dwi Astuti, Asrining Surasmi \\ Kementerian Kesehatan Politeknik Kesehatan Surakarta Jurusan Keperawatan
}

\begin{abstract}
Health Education, Demonstration Method, Breastfeeding Ability. This study aims to know the effect of health education of the right way to breast-feed with demonstration method toward mothers ability to breast-feed in maternity hospital, Banjarsari, Surakarta. This research is Pre-experimental with the draft of one group pre-post test design. The samples are 30 breastfeeding mothers in maternity hospital in Banjarsari, Surakarta. The measurement conducted twice, before and after they were given counseling with demonstration method. The result the mean of breastfeeding ability before counseling is 61,77 with standard deviation 13,423 and after counseling 95,57 with standard deviation 5,661. The development of the mean of mothers ability before and after counseling is different. It mean p 0,00. There was significant impact between mother's breastfeeding ability before and after counseling with demonstration method have done.
\end{abstract}

Keyword : Health Education, Demonstration Method, Breastfeeding Ability

Abstrak : Penyuluhan Kesehatan, Metode Demonstrasi, Kemampuan Menyusui. Tujuan penelitian untuk mengetahui pengaruh Penyuluhan Kesehatan tentang Menyusui yang Benar dengan Metode Demonstrasi terhadap Kemampuan Ibu dalam Menyusui di Rumah Bersalin Wilayah Kecamatan Banjarsari Surakarta. Metode Penelitian penelitian ini adalah pre eksperimental, dengan rancangan one group pre-post test design. Sampel yang digunakan ibu menyusui di Rumah Bersalin Wilayah Banjarsari Surakarta sebanyak 30 orang. Pengukuran kemampuan menyusui dilakukan 2 kali sebelum dan sesudah diberikan penyuluhan dengan metode demonstrasi. Hasil rerata nilai kemampuan menyusui sebelum perlakuan 61,77 dengan standar deviasi 13,423 dan setelah perlakuan 95,57 dengan standar deviasi 5,661. Peningkatan rerata kemampuan ibu sebelum dan setelah perlakuan berbeda bermakna p 0,0.Ada pengaruh yang signifiasikan antara kemampuan ibu menyusui sebelum dan sesudah dilakukan penyuluhan dengan metode demonstrasi

Kata Kunci : Penyuluhan Kesehatan, Metode Demonstrasi, Kemampuan Menyusui

\section{PENDAHULUAN}

Modal dasar pembentukan manusia berkualitas dimulai sejak bayi dalam kandungan dan selama 5 tahun pertama kehidupan anak. Kualitas dalam kandungan diperoleh, apabila seorang ibu bisa memberi nutrisi yang baik untuk tumbuh kembang bayi selama masa kehamilan. Sedangkan di luar kandungan di mulai dengan pemberian nutrisi yang 
tepat bagi bayi yaitu ASI yang diperoleh ketika bayi menyusu pada ibunya, karena ASI memelihara pertumbuhan dan perkembangan otak bayi, sistem kekebalan dan faal tubuh secara optimal, dan merupakan faktor yang vital untuk mencegah penyakit terutama diare dan infeksi saluran nafas (termasuk pnemonia).

\section{Menyusui}

pengeluaran hormon pertumbuhan, meningkatkan perkembangan mulut yang sehat dan membangun hubungan saling percaya antara ibu dan bayi, (Depkes RI,2004). Menyusui telah dikenal dengan baik sebagai cara untuk melindungi, meningkatkan dan mendukung kesehatan bayi dan anak usia dini dan merupakan kewajiban yang dilakukan oleh seorang ibu guna memenuhi kebutuhan tumbuh kembang bayi yang dilahirkannya. Keberhasilan atau kemampuan seorang ibu untuk bisa memberikan ASI kepada anak merupakan Anugerah Tuhan Yang Maha Esa yang tak ternilai harganya, hal ini dikarenakan di dalam ASI terkandung zat kekebalan yang tak akan dimilik oleh semua jenis susu formula yang ada di Indonesia. Namun demikian menyusui tidak hanya sekedar memberikan minum dengan cara mengisap puting susu saja, karena tanpa bimbingan yang tidak benar dan tidak teratur dari tenaga kesehatan akan menimbulkan banyak kendala dalam pemberian ASI terutama pada ibu primipara. Hal ini seringkali kurang disadari oleh ibu-ibu primiprara di Indonesia. Selain kurangnya informasi juga disebabkan oleh beberapa faktor eksternal yang lain.

Sebagai seorang ibu pasti memiliki kodrat dan naluri untuk menyusui anaknya. Namun demikian beberapa kendala dalam menyusui seringkali dihadapi oleh ibu-ibu, diantaranya belum ada pengalaman, ketidak telatenan dalam memberi ASI dan kurangnya informasi dalam menyusui sehingga akan memicu emosional ibu, dengan demikian membuat ibu putus asa untuk menyusui. Pada kondisi ibu menyusui memerlukan dukungan dari berbagai pihak, terutama dukungan pengetahuan dan dukungan moril dari orang-orang terdekat. Hal penting yang harus perhatikan dalam memberikan ASI adalah bagaimana cara menyusui yang benar, karena dengan menyusui yang benar akan menghindarkan ibu dari dari masalah puting susu lecet, kesakitan dan ketidaknyamanan dalam menyusui dan rasa enggan dalam menyusui. Mengingat banyaknya kendala terutama pada ibu primi dalam menyusui, maka dukungan pengetahuan menyusui yang cukup pada ibu khususnya ibu primipara sangat membantu dalam mengatasi kendala yang selama ini sering mempengaruhi ibu dalam menyusui.

Kegagalan menyusui sering kali disebabkan karena kesalahan memposisikan dan meletakkan bayi. Puting ibu menjadi lecet dan menimbulkan luka yang terkadang membuatnya menjadi malas untuk menyusui, sehingga menyebabkan produksi ASI berkurang dan pada akhirnya si kecil pun menjadi malas menyusu. Jika kondisi seperti terus berlanjut, bisa jadi proses menyusui akan terhenti dan si bayi akan kehilangan manfaat ASI yang luar biasa bagi pertumbuhannya. Padahal kita mengetahuinya bahwa peranan ASI itu sangat penting sekali untuk si kecil. si kecil $0-6$ Bulan itu sebenarnya wajib menyusui, bahkan sampai 2 tahun. sebaik - baiknya susu formula lebih baikkan ASI 
Ekslusif. Edukasi tentang pemberian ASI perlu terus ditingkatkan. Dukungan dan bimbingan dari keluarga serta lingkungan juga sangat penting diberikan bagi para ibu agar para ibu bersemangat dan paham akan pentingnya pemberian ASI ini.

\section{METODOLOGI PENELITIAN}

Jenis penelitian yang digunakan dalam penelitian ini adalah pre eksperimental, dengan rancangan one group pre-post test design. Rancangan ini mengungkapkan hubungan sebab akibat dengan cara melibatkan satu kelompok. Kelompok subyek diobervasi sebelum dilakukan intervensi kemudian diobservasi lagi setelah dilakukan intervensi (Nursalam. 2008)

\section{HASIL PENELITIAN}

Nilai kemampuan menyusui responden sebelum diberikan penyuluhan dengan metode demonstrasi. Hasil nilai kemampuan menyusui responden sebelum diberikan penyuluhan dengan metode demonstrasi dapat dijelaskan pada tabel di bawah ini.

\section{Tabel 1}

Nilai Rerata Kemampuan Menyusui Responden Sebelum Dan Sesudah Diberikan Penyuluhan Dengan Metode Demonstrasi

\begin{tabular}{llllll}
\hline & & & & & Std. \\
& & & & Std. & Error \\
Deviation & Mean \\
\hline Pair 1 & sebelum & 61.77 & 30 & 13.423 & 2.451 \\
& sesudah & 95.57 & 30 & 5.661 & 1.034 \\
\hline
\end{tabular}

Dari hasil uji statistik pada tabel 1 di dapatkan nilai rerata kemampuan menyusui responden sebelum diberikan penyuluhan dengan metode demonstrasi 61,77 dengan standar deviasi 13,423

Nilai kemampuan menyusui responden setelah diberikan penyuluhan dengan metode demonstrasi Hasil nilai kemampuan menyusui responden setelah diberikan penyuluhan dengan metode demonstrasi pada tabel 5.4 di atas. didapatkan nilai rerata 95,57 dengan standar deviasi 5,661

Pengaruh penyuluhan kesehatan tentang menyusui yang benar dengan metode demontrasi terhadap kemampuan ibu menyusui. Hasil uji statistik pengaruh penyuluhan kesehatan tentang menyusui yang benar dengan metode demontrasi terhadap kemampuan ibu menyusui dapat dijelaskan pada tabel di bawah ini.

\section{Tabel 2}

Pengaruh Penyuluhan Kesehatan

Tentang Menyusui Yang Benar Dengan Metode Demontrasi Terhadap Kemampuan Ibu Menyusui

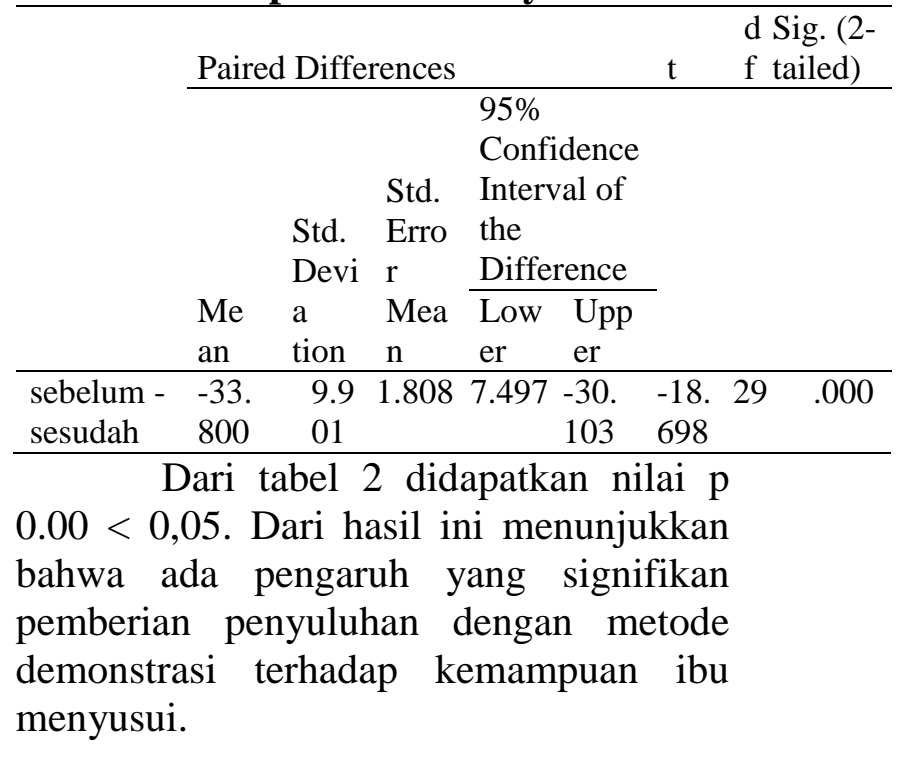

\section{PEMBAHASAN}

Nilai kemampuan menyusui responden sebelum diberikan penyuluhan dengan metode demonstrasi. Hasil uji statistik di dapatkan hasil nilai rerata kemampuan menyusui responden sebelum diberikan penyuluhan dengan metode demonstrasi 61,77 dengan standar deviasi 
13,423 . Rendahnya nilai rerata sebelum dilakukan tindakan demonstrasi dikarenakan ketika menyusui ibu tidak pernah memperhatikan teknik menyusu yang benar dan hanya didasarkan oleh kewajiban sebagai seorang ibu untuk menyusui anaknya. Selain itu berdasarkan pendapat ibu, penyuluhan kesehatan yang sering kali diberikan hanya dalam bentuk ceramah dan diberikan leaflet sehingga sering kali lupa terhadap apa yang sudah di jelaskan. Hal ini dijelaskan dalam teori Edgar Dale, 1964 dalam Nursalam dan Efendi, 2008 yang menyatakan bahwa dengan membaca atau mendengar seseorang akan dapat mengingat $10 \%$ dari yang dibaca atau didengarnya seperti dalam bentuk leaflet, slide, booklet, dan sejenisnya, mendengar (tape atau pembicaraan orang lain), maka ia akan mengingat $20 \%$ dari apa yang didengarnya; melihat (bagan, foto, dan grafik), maka ia akan mengingat $30 \%$ dari apa yangdilihatnya; mendengar dan melihat (melihat demonstrasi, film, dan video), maka ia akan mengingat 50\% dari apa yang didengar dan dilihatnya; mengucapkan sendiri kata-katanya (media wayang, script, dan drama), maka ia akan mengingat $70 \%$ dari apa yang diucapkannya; dan mengucapkan sambil mengerjakan sendiri suatu materi pendidikan kesehatan (biasanya menggunakan media yang mirip dengan objek yang sebenarnya dan melalui pengalaman yang nyata), maka ia akan mengingat $90 \%$ dari materi tersebut. Informasi tentang cara-cara menyusui yang baik dan benar, pemberian ASI Eksklusif belum menjangkau sebagian besar ibu-ibu (Depkes RI, 2005)

Pengaruh pendidikan kesehatan dengan menggunakan metode demontrasi terhadap kemampuan ibu menyusui. Hasil uji statistik didapatkan nilai Sig. 2-tailed $0,00<0,05$. Dari hasil ini menunjukkan bahwa ada pengaruh yang signifikan pemberian penyuluhan dengan metode demonstrasi terhadap kemampuan ibu menyusui. Hal ini sesuai dengan penelitian Adriyani (2011) ada pengaruh signifikan antara pemberian demonstrasi perawatan payudara dengan terhadap kelancaran ASI. Metode demonstrasi sangatlah berpengaruh terhadap daya serap dan minat seseorang dalam belajar. Dikarenakan metode ini mempunyai banyak kelebihan dalam pembelajaran, diantaranya membuat pelajaran menjadi lebih jelas dan lebih konkrit serta menghindari verbalisme, memudahkan seseorang memahami bahan pelajaran, proses pengajaran akan lebih menarik, merangsang seseorang untuk lebih aktif mengamati dan dapat mencobanya sendiri. Sedangkan Wardani (2011) yang melakukan penelitian di Surakarta mengemukakan bahwa prestasi belajar dengan penerapan metode demonstrasi lebih baik jika dibandingkan dengan penerapan metode ceramah. Hal senada senada juga disampaikan dalam penelitian Darmiastuty (2004) bahwa proses belajar dengan metode demonstrasi memicu remaja untuk lebih mendalami pengetahuan yang mereka miliki dengan cara mengaktifkan kembali pengetahuan yang dimiliki, mengolah pengetahuan tersebut kemudian mengorganisasi pengetahuan tersebut sehingga pengetahuan yang diperoleh dapat tertahan erat dalam sistem penyimpanan dan sulit dilupakan. Penggunaan alat peraga (phantom) dapat mengoptimalkan kualitas belajar siswa. Hal ini sesuai dengan yang disampaikan Depkes RI (2005) kurangnya pengertian dan keterampilan ibu menyusui tentang 
keunggulan ASI dan manfaat ASI menyebabkan mereka mudah terpengaruh oleh promosi susu formula yang sering dinyatakan sebagai pengganti air susu ibu, sehingga dewasa ini semakin banyak ibu menyusui memberikan susu botol yang sebenarnya merugikan mereka.

\section{KESIMPULAN DAN SARAN}

Berdasarkan hasil penelitian dapat ditarik kesimpulan nilai rerata kemampuan menyusui responden sebelum 61,77 dengan standar deviasi 13,423 dan setelah 95,57 dengan standar deviasi 5,661 diberikan penyuluhan dengan metode demonstrasi mengalami peningkatan yang signifikan. Hasil uji statistik paires $t$ test didapatkan nilai Sig. 2-tailed $0.00<0,05$ menunjukkan bahwa ada pengaruh yang signifikan pemberian penyuluhan dengan metode demonstrasi terhadap kemampuan ibu menyusui

Berdasarkan kesimpulan di atas disarankan pada pelaksanaan penyuluhan kesehatan, sebaiknya dilakukan dengan pendekatan demonstrasi, karena metode demonstrasi terbukti dapat meningkatkan kemampuan ibu dalam menyusui, sehingga ibu dapat menyusui dengan teknik yang benar. Berdasarkan hasil penelitian ini, penyuluhan kesehatan khususnya metode demonstrasi yang dilakukan terbukti berpengaruh secara signifikan dalam meningkatkan kemampuan menyusui. Oleh sebab itu, dalam setiap memberikan penyuluhan hendaknya menggunakan metode demonstrasi.

\section{DAFTAR RUJUKAN}

Darmiastuty, Meita. 2004. Efektivitas metode ceramah tanya jawab dan simulasi dalam meningkatkan pengetahuan dan sikap ibu tentang pencegahan dini penyalahgunaan narkoba pada remaja SLTP 1 Borobudur Kabupaten Magelang. Semarang: Pasca Sarjana Universitas Diponegoro

Departemen Kesehatan RI,(2005) Pusat Promosi Kesehatan, Pengembangan Media Promosi Kesehatan, Jakarta

Depkes, JHPIEGO,(2004), Buku Acuan Nasional Kesehatan Maternal dan Neonatal, Jakarta, Depkes RI

Efendi, Ferry dan Makhfudli. 2009. Keperawatan Kesehatan Komunitas: Teori dan Praktik dalam Keperawatan. Salemba Medika, Jakarta.

Nursalam, (2008), Konsep dan Penerapan Metodologi Penelitian Ilmu Keperawatan, Jakarta, Salemba Medika.

Suradi R, Tobing P (2004), Manajemen Laktasi, cetakan ke-2, Program Manajemen Laktasi Perkumpulan Perinatologi Indonesia, Jakarta.

Wardani, Riska Aprilia. 2011. Pengaruh Metode Demonstrasi Terhadap Prestasi Belajar Mata Kuliah ASKEB II Persalinan (Standart Asuhan Persalinan Normal) Ditinjau dari Motivasi Belajar pada Mahasiswa Prodi Kebidanan STIKES Dian Husada Mojokerto 